\title{
Genome-wide identification and expression analysis of the CLC gene family in pomegranate (Punica granatum) reveals its roles in salt resistance
}

\author{
Cuiyu Liu ${ }^{1,2}$, Yujie Zhao ${ }^{1,2}$, Xueqing Zhao ${ }^{1,2}$, Jianmei Dong ${ }^{1,2}$ and Zhaohe Yuan ${ }^{1,2^{*}}$
}

\begin{abstract}
Backgrounds: Pomegranate (Punica granatum L.) is an important commercial fruit tree, with moderate tolerance to salinity. The balance of $\mathrm{Cl}^{-}$and other anions in pomegranate tissues are affected by salinity, however, the accumulation patterns of anions are poorly understood. The chloride channel (CLC) gene family is involved in conducting $\mathrm{Cl}^{-}, \mathrm{NO}_{3}{ }^{-}, \mathrm{HCO}_{3}{ }^{-}$and $\mathrm{I}^{-}$, but its characteristics have not been reported on pomegranate.

Results: In this study, we identified seven PgCLC genes, consisting of four antiporters and three channels, based on the presence of the gating glutamate $(E)$ and the proton glutamate $(E)$. Phylogenetic analysis revealed that seven PgCLCs were divided into two clades, with clade I containing the typical conserved regions GxGIPE (I), GKxGPxxH (II) and PxxGXLF (III), whereas clade II not. Multiple sequence alignment revealed that PgCLC-B had a P [proline, Pro] residue in region I, which was suspected to be a $\mathrm{NO}_{3}{ }^{-} / \mathrm{H}^{+}$exchanger, while PgCLC-C1, PgCLC-C2, PgCLC-D and PgCLC-G contained a S [serine, Ser] residue, with a high affinity to $\mathrm{Cl}^{-}$. We determined the content of $\mathrm{Cl}^{-}, \mathrm{NO}_{3}{ }^{-}$, $\mathrm{H}_{2} \mathrm{PO}_{4}{ }^{-}$, and $\mathrm{SO}_{4}{ }^{2-}$ in pomegranate tissues after 18 days of salt treatments $(0,100,200$ and $300 \mathrm{mM} \mathrm{NaCl})$. Compared with control, the $\mathrm{Cl}^{-}$content increased sharply in pomegranate tissues. Salinity inhibited the uptake of $\mathrm{NO}_{3}{ }^{-}$and $\mathrm{SO}_{4}{ }^{2-}$, but accelerated $\mathrm{H}_{2} \mathrm{PO}_{4}{ }^{-}$uptake. The results of real-time reverse transcription PCR (qRT-PCR) revealed that $P g C L C$ genes had tissue-specific expression patterns. The high expression levels of three antiporters $P g C L C-C 1, P g C L C-C 2$ and PgCLC-D in leaves might be contributed to sequestrating $\mathrm{Cl}^{-}$into the vacuoles. However, the low expression levels of PgCLCs in roots might be associated with the exclusion of $\mathrm{Cl}^{-}$from root cells. Also, the up-regulated $\mathrm{PgCLC}-\mathrm{B}$ in leaves indicated that more $\mathrm{NO}_{3}{ }^{-}$was transported into leaves to mitigate the nitrogen deficiency.
\end{abstract}

Conclusions: Our findings suggested that the PgCLC genes played important roles in balancing of $\mathrm{Cl}^{-}$and $\mathrm{NO}_{3}{ }^{-}$in pomegranate tissues under salt stress. This study established a theoretical foundation for the further functional characterization of the CLC genes in pomegranate.

Keywords: CLC gene family, Phylogenetic analysis, Anion content, Expression pattern, $\mathrm{NaCl}$ stress

\footnotetext{
* Correspondence: zhyuan88@hotmail.com

${ }^{1}$ Co-Innovation Center for Sustainable Forestry in Southern China, Nanjing Forestry University, Nanjing 210037, China

${ }^{2}$ College of Forestry, Nanjing Forestry University, Nanjing 210037, China
}

(c) The Author(s). 2020 Open Access This article is licensed under a Creative Commons Attribution 4.0 International License, which permits use, sharing, adaptation, distribution and reproduction in any medium or format, as long as you give appropriate credit to the original author(s) and the source, provide a link to the Creative Commons licence, and indicate if changes were made. The images or other third party material in this article are included in the article's Creative Commons licence, unless indicated otherwise in a credit line to the material. If material is not included in the article's Creative Commons licence and your intended use is not permitted by statutory regulation or exceeds the permitted use, you will need to obtain permission directly from the copyright holder. To view a copy of this licence, visit http://creativecommons.org/licenses/by/4.0/ The Creative Commons Public Domain Dedication waiver (http://creativecommons.org/publicdomain/zero/1.0/) applies to the data made available in this article, unless otherwise stated in a credit line to the data. 


\section{Background}

Pomegranate (Punica granatum L.), a salt-tolerant plant, is widely grown in the arid and semiarid regions, where is always suffering the soil salinization [1]. Bhantana et al. [2] reported that pomegranate could be used as a model plant for deciduous fruit trees to study the responses to environmental stresses. In our previous study, we found that the $\mathrm{Cl}^{-}$content was two times more than the $\mathrm{Na}^{+}$content in pomegranate tissues, and uptake of other anions was also affected by various concentration of salinity [3]. Chlorine is an essential micronutrient for plants, predominantly occurring in the form of $\mathrm{Cl}^{-}[4,5]$. It is mainly involved in plant physiological activities, such as photosynthesis, regulation of stomatal opening and closing, stabilization of the membrane potential, regulation of intracellular $\mathrm{pH}$ gradients and electrical excitability [5]. Excess and/or deficiency of $\mathrm{Cl}^{-}$leads to weak plant growth, low yield and poor quality $[6,7]$. In a salinized environment, mostly caused by high $\mathrm{NaCl}$, the foliar salt damage of some plants was mainly caused by $\mathrm{Na}^{+}$[8], while that of other plants, such as tobacco (Nicotiana tabacum) [7], grape (Vitis vinifera) [9], citrus (Citrus aurantium) [10] and soybean (Glycine max) [11, 12] was mainly caused by $\mathrm{Cl}^{-}$. Previous researches reported that the accumulation patterns of anions, such as $\mathrm{Cl}^{-}, \mathrm{NO}_{3}{ }^{-}$, $\mathrm{HCO}_{3}{ }^{-}$, and $\mathrm{SO}_{4}{ }^{2-}$ in plant tissues were associated with the plant salt tolerance [6]. Also, the $\mathrm{NO}_{3}{ }^{-} / \mathrm{Cl}^{-}$even equal to the $\mathrm{K}^{+} / \mathrm{Na}^{+}$, which was confirmed as one of the critical determinants of plant salt resistance $[8,13]$. Therefore, the study on the underlining mechanisms between uptake and transport of $\mathrm{Cl}^{-}$and other anions in pomegranate tissues and salinity conditions was contributed to elucidate the pomegranate salt tolerance.

Chlorine channel (CLC) proteins are highly associated with uptake and transport of these anions, like $\mathrm{Cl}^{-}$, $\mathrm{NO}_{3}{ }^{-}, \mathrm{HCO}_{3}{ }^{-}, \mathrm{I}^{-}$, and $\mathrm{Br}^{-}$[14-17]. The first CLC family gene $(C L C-O)$ was identified from the electric organ of marine ray (Torpedo marmorata) [18], and since then, some new members have been found in bacteria, yeast, mammals and plants [19]. In land plants, the first CLC gene, CLC-Nt1, was cloned in tobacco [20]. Subsequently, numerous CLC gene homologues were isolated from Arabidopsis [21], rice (Oryza sativa) [22], soybean (Glycine max) and trifoliate orange (Poncirus trifoliata) [23], etc. All of the CLC proteins have a highly conserved voltage-gated chloride channel (Voltage-gate CLC) domain and two CBS (cystathionine beta synthase) domains of putative regulatory function [14]. Also, the CLC gene family members contain three highly conserved regions related to anion selectivity: GxGIPE (I), GKxGPxxH (II) and PxxGxLF (III) [24]. If the $x$ residue in the conserved region (I) is $\mathrm{P}$ [proline, Pro], $\mathrm{NO}_{3}{ }^{-}$is preferentially transported, whereas if it is substituted by $\mathrm{S}$ [serine, Ser], $\mathrm{Cl}^{-}$is preferentially transported [25]. The first $x$ residue in conserved region II and the next fourth residue of the conserved region III can both be $\mathrm{E}$ (Glu) residue, which are signatures for CLC antiporters [26, 27]. However, if any other amino acids are found at these positions, such as in AtCLCe, AtCLCf and AtCLCg, these proteins may exert CLC channels activity [27]. Therefore, CLC proteins may act as $\mathrm{Cl}^{-}$channels or as $\mathrm{Cl}^{-} / \mathrm{H}^{+}$-exchangers (antiporters) [19]. The $\mathrm{Cl}^{-}$channels mediate passive transport by dissipating pre-existing electrochemical gradients, while the antiporters mediate active transport by coupling with energy consumption to move the substrate against an electrochemical gradient [27]. In higher plants, CLC proteins play vital roles in the control of electrical excitability, turgor maintenance, stomatal movement, ion homeostasis, as well as in responses to biotic and/or abiotic stress [28-30].

In Arabidopsis, there are seven reported CLC genes: AtCLCa AtCLCg, which play different roles in diverse cell organelles [28, 31]. Barbierbrygoo et al. [32] and Marmagne et al. [33] suggested that AtCLCa AtCLCd and AtCLCg were clustered into a distinct branch, belonging to eukaryotic CLCs, while AtCLCe and AtCLCf are closely related to prokaryotic CLC channels. AtCLCa codes for an $\mathrm{NO}_{3}{ }^{-} / \mathrm{H}^{+}$exchangers localized in the vacuolar membrane, which is critically involved in this nitrate accumulation in the vacuole [21]. AtCLCb, coding for a vacuolar antiporter, shares $80 \%$ identity with $A t C L C a$, is highly expressed in young roots, hypocotyl and cotyledons [34]. AtCLCc is essential for the detoxification of cytosol by sequestrating $\mathrm{Cl}^{-}$into the vacuoles under salt stress, and it is strongly expressed in guard cells, pollen and roots [28]. AtCLCd and AtCLCf, both localized in Golgi membranes, may play a role in the acidification of the trans-Golgi vesicles network [31, 33], while AtCLCe is targeted to the thylakoid membranes in chloroplasts [33]. AtCLCg, the closest homolog to AtCLCc (62\% identity), plays a physiological role in the $\mathrm{Cl}^{-}$homeostasis during $\mathrm{NaCl}$ stress [35]. In other plants, many CLC genes are involved in anions transport and in the response to salt stress. For instance, the expression level of OsCLC-1 is upregulated in rice under $\mathrm{NaCl}$ stress [22]; PtrCLC genes are profoundly induced in orange by salt stress [23]; GmCLC1 has been found to enhanced salt tolerance in transgenic Arabidopsis seedlings by reducing the $\mathrm{Cl}^{-}$accumulation in shoots [36]; and GsCLC-c2 over-expression contributes to $\mathrm{Cl}^{-}$and $\mathrm{NO}_{3}{ }^{-}$homeostasis, and therefore confers the salt tolerance on wild soybean [37].

However, the characteristics of the $C L C$ genes have not been reported on pomegranate. Therefore, this study made a comprehensive, genome-wide inventory of the CLC gene family in pomegranate. In order to reveal the accumulation patterns of $\mathrm{Cl}^{-}$and other anions in pomegranate tissues and the roles of $P g C L C s$ in uptake and transport of these anions, we also determined the anions 
contents and the expression levels of PgCLCs in pomegranate tissues under different $\mathrm{NaCl}$ concentration, which would comprehensively illuminate the accumulation patterns of anions under $\mathrm{NaCl}$ stress, and provide a reference for the further study on functions of the $C L C$ gene.

\section{Results}

\section{Identification of the CLC genes in pomegranate}

A HMM profile was used to identify the putative $C L C$ genes in pomegranate genome. All seven putative $C L C$ genes contained a highly conserved Volgate_CLC domain and two CBS domains, and they were named $P g C L C-B$ to $P g C L C-G$ according to the homologous AtCLCs (Table 1). The analysis of protein sequences showed that the PgCLCs contained 698 797 amino acids and had molecular weights of $75.7 \sim 87.9 \mathrm{kDa}$. The predicted isoelectric points (pI) of all the PgCLC proteins ranged from 5.86 to 8.44. The grand average of the hydrophobicity (GRAVY) values were all positive values, indicating that the PgCLCs were hydrophobic proteins. There were a number of transmembrane helices (TMHs) in the PgCLCs, ranging from 9 to 11, which were associated with the ion transport.

\section{Phylogenetic analysis of the CLC gene family in pomegranate}

To elucidate the evolutionary traits of the CLC gene family in land plants, we investigated 15 interesting species that had available reference genome sequences. Our results showed two obvious clades of the CLC gene tree, clade I was the major group bearing a moderate support $(\mathrm{BS}=61 \%$, Fig. $\mathrm{S} 1$ ) and clade II contained two subgroups (Fig. 1). PgCLC-E and PgCLC-F were belonged to clade II and other PgCLCs were belonged to clade I. The divergence of clades I and II might have occurred before the origin of land plants due to each clade consisting of taxa from embrophytes (Fig. 1). Phylogenetic analyses indicated multiple rounds of ancient gene expansion (Fig. 1). The diversity of gene copy number from different lineages (Fig. 1a). The gene tree-species tree reconcilably identified a gene duplication (the red star in Fig. 1b) with a strongly supported $(\mathrm{BS}=100$, Fig.S1) topology of (core eudicots, core eudicots), which was contributed to the duplication between PgCLC-C1 and PgCLC-C2. A gene duplication (the purple star in Fig. 1b) resulting in a topology of ((core eudicots, monocots), (core eudicots, monocots)) was identified as one duplicate shared by angiosperms, which was associated with the duplication between PgCLC-C and PgCLC-G. Our phylogenetic analyses also found gene expansion in seed plants, with a gene birth from an ancient gene duplication (the green star in Fig. 1b) and a subsequent gene death. The tree topology [(angiosperms, gymnosperms) angiosperms] of the CLCA/B/C/G genes (Fig. 1) exhibited a gene loss event in gymnosperms. There were two members from Arabidopsis and Eutrema in the CLC-A/B subfamily, while only one member PgCLC-B from pomegranate.

Here, our phylogenetic results showed that seven putative $P g C L C$ genes originated before the divergence of land plants and were retained after experiencing six times of duplications, including at least one ancient core eudicots-specific duplication (PgCLC-C1 and PgCLC$\mathrm{C} 2$ ) and one angiosperm-specific expansion (PgCLC-C1/ C2 and PgCLC-G) (Fig. 1, Fig. S1).

\section{Conserved motifs and residues of the CLC gene family}

To further investigate the structural diversity of all CLCs in land plants, the conserved motifs and regions were analyzed. Here, a total of ten motifs were selected, referring as motif $1-10$, and five representative species of each taxa were shown (Fig. 2b, Fig. S1B). Different motif patterns were clearly observed in the two clades, as mentioned above (Fig. 1b). For clade I, most of the CLCs possessed ten motifs (Fig. 2b, c; Fig. S2). For clade II, most of the CLC-E and CLC-F proteins possessed four motifs: 6, 1, 8 and 2, which were shared by all of the CLCs of clade I. Three conserved regions GxGIPE (I), GKxGPxxH (II) and PxxGxLF (III) were included in motif 9, motif 6 and motif 1 , respectively (Fig. $2 \mathrm{~b}, \mathrm{c}$ and $\mathrm{d}$ ). Three highly conserved regions of the CLC gene family were shared by members of clade I, whereas they were not shared by members of clade II (Fig. 2b, c; Fig. S2).

Table 1 Characteristics of the CLC genes in pomegranate

\begin{tabular}{llllllll}
\hline Gene ID & Name & Length & Mw (kDa) & pl & GRAVY & Orthologs & TMHs \\
\hline CDL15_Pgr005627 & PgCLC-B & 797 & 87.9 & 6.49 & 0.259 & AtCLC-B \\
CDL15_Pgr027626 & PgCLC-C1 & 698 & 75.7 & 7.53 & 0.364 & AtCLC-C \\
CDL15_Pgr013895 & PgCLC-C2 & 717 & 78.1 & 5.92 & 0.325 & AtCLC-C \\
CDL15_Pgr008552 & PgCLC-D & 788 & 86.9 & 8.57 & 0.175 & AtCLC-D \\
CDL15_Pgr019810 & PgCLC-E & 764 & 81.3 & 5.86 & 0.188 & AtCLC-E \\
CDL15_Pgr012201 & PgCLC-F & 765 & 81.7 & 6.54 & 0.035 & AtCLC-F \\
CDL15_Pgr015371 & PgCLC-G & 709 & 77.3 & 8.44 & 0.468 & AtCLC-G & 11 \\
\hline
\end{tabular}

Note: molecular weight $(\mathrm{Mw})$, isoelectric points ( $\mathrm{pl}$ ), grand average of the hydrophobicity (GRAVY), transmembrane helices (TMHs) 
A

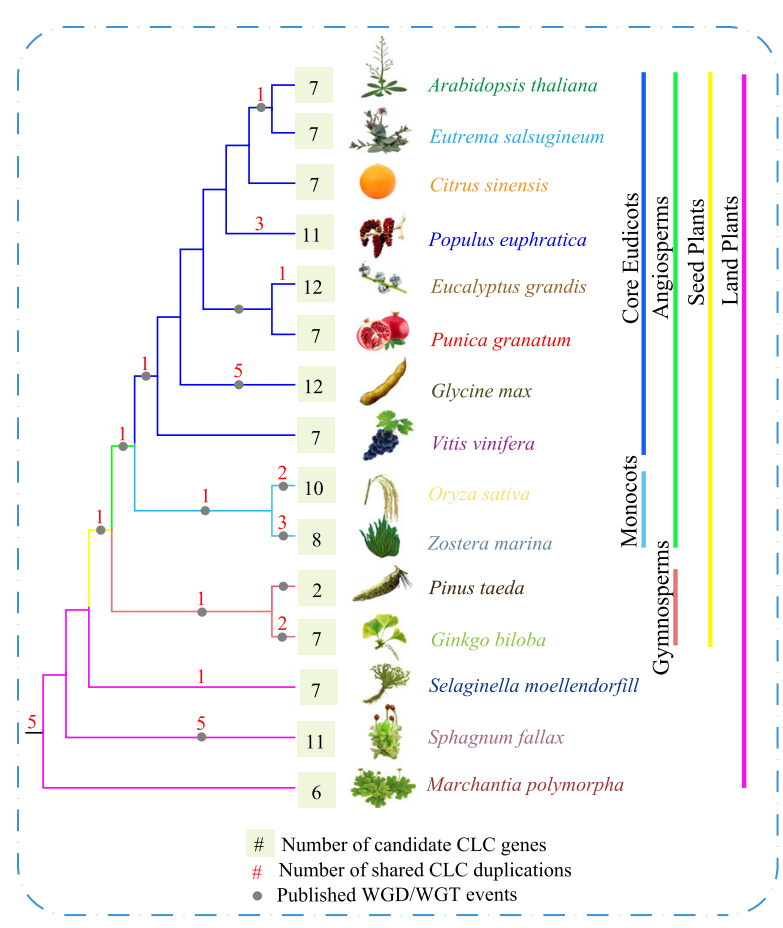

B

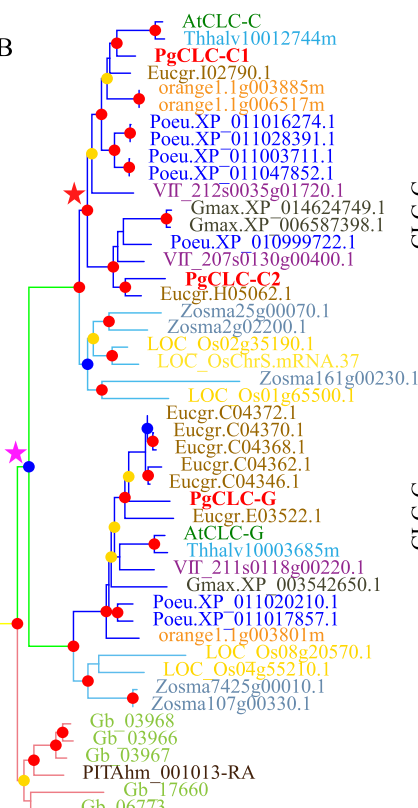

-

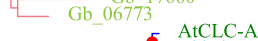

AtCLC-A

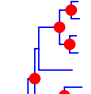

AtCLC B $27650 \mathrm{~m}$ AtCLC-B Orange $1.10013262 \mathrm{~m}$
Gmax XP 014624104.1 Gmax.XP 014624104.1 Gmax.NP 001236494 $\mathrm{PgClC}-\mathrm{B}^{-}$
$\mathrm{Bucgr} .101654$ L VIT 214 s0068g02190.1

Selmo442632

- Sphfalx02G053600.

Sphfal $\times 1$ 0067000.

Sphffalx $01 \mathrm{G} 195000.1$

Mapoly0100s 0037.1

Thhalv1000364

2orangel.1900389m

Gou.XP 011021556.1

Poeu.XPr.F01498.1

PgCLC-D

$\longrightarrow$ VIT 205s0020g03090.1

- Mapoly0063 0301894

Sohfar14G0008000.1

Selmo80232

$\square \quad$ - Mapoly0026s0078.

$\underline{0.2}$

Bootstrap values (BS)

51 75

: 76 $91 \sim 100$

$\longrightarrow$ Sphtalx12G033

Gmax.XP 006604169.1

Gmax.XP- 003527569.1
Gmax XP- 003522836.1

- Eucgr.F01982.

— Poceu.XP 011007031.1

AtCLC-F

L VIT 21980015001850.

Z Z Z

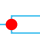

LoC Os08938980.1

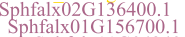

Mapoly0179s0012.1 042400.1

Mapoly0001s0400 Selmo8064

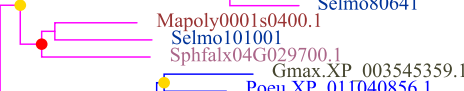

Clade II

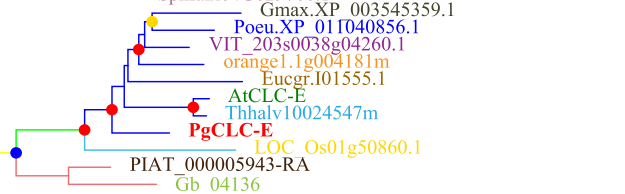

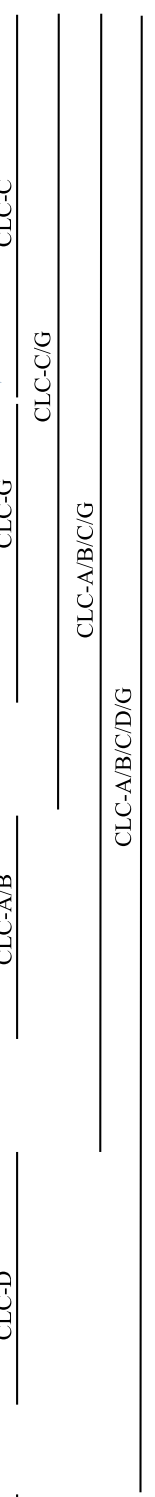

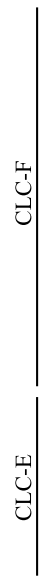

Fig. 1 Phylogenetic analysis of the CLC gene family in land plants. a Species tree with different branch colors showing distinct species. b Phylogenetic tree of the CLC gene family in land plants presented in various branch colors, as in Fig. a. Node support (pots) was quantified by aLRT statistics with the SH-like procedure. Colored stars are gene duplication events 


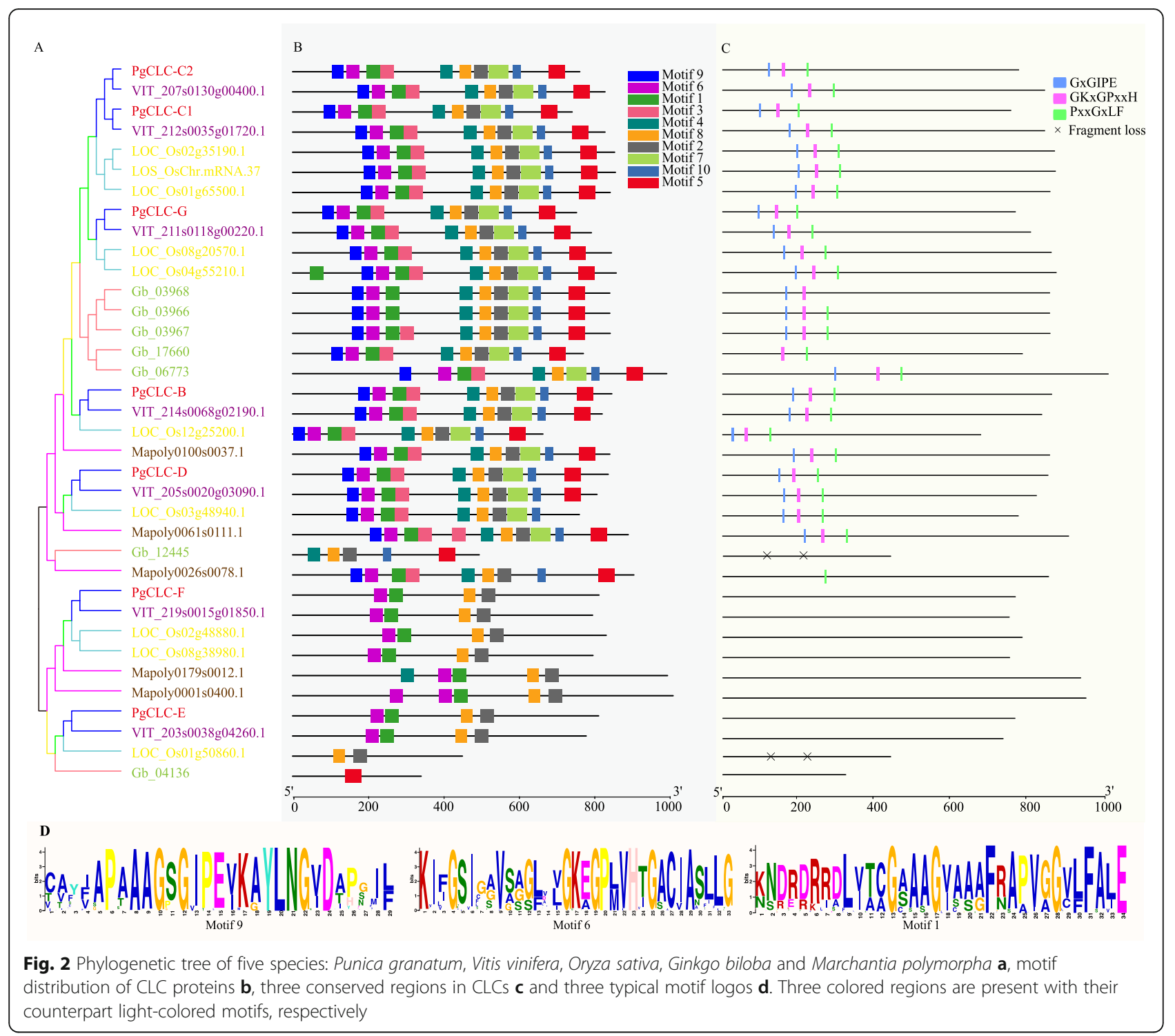

Additionally, to meticulously analyze the conserved regions of CLC proteins, multiple sequence alignment was performed. Members of the CLC-A/B subfamily had a P [proline, Pro] residue in the conserved region GxGIPE (I), while other proteins of the CLC-C, CLC-G and CLC-D subfamilies in clade I had a $\mathrm{S}$ [serine, Ser] residue in the conserved region I (Fig. 3a). These critical residues were recognized to have a close relation with anion selectivity. The $\mathrm{P}$ [proline, Pro] preferentially transported $\mathrm{NO}_{3}{ }^{-}$, whereas the $\mathrm{S}$ [serine, Ser] preferentially transported $\mathrm{Cl}^{-}$(Fig. 3a). Thus, PgCLC-B was likely a $\mathrm{NO}_{3}{ }^{-} / \mathrm{H}^{+}$exchanger that mainly transported $\mathrm{NO}_{3}{ }^{-}$, while PgCLC-C, PgCLC-D and PgCLC-G might preferentially transported $\mathrm{Cl}^{-}$. The presence of the conserved gating glutamate (E) in conserved region (II) and the proton glutamate $(\mathrm{E})$ residues in the next fourth residue of the conserved region (III) were signatures for CLC antiporters. Otherwise, the conserved gating glutamate (E) of the CLC-G subfamily and the proton glutamate (E) residue of the CLC-E and CLC-F subfamilies were substituted by other amino acids (Fig. 3a), which suggested that the members of these three subfamilies might be CLC channels. Based on these results, we assumed that four PgCLC proteins (PgCLC-B, PgCLC-C1, PgCLC-C2 and PgCLC-D) were CLC antiporters, while the other three PgCLCs (PgCLC-E, PgCLC-F and PgCLC-G) were likely CLC channels (Fig. 3a, b).

\section{Growth characteristics and anion contents in pomegranate tissues}

With the increasing concentration of salinity, dry weights of roots and stems showed no significant changes among each treatment (Table S4, $p<0.05$ ). While leaf dry weight 


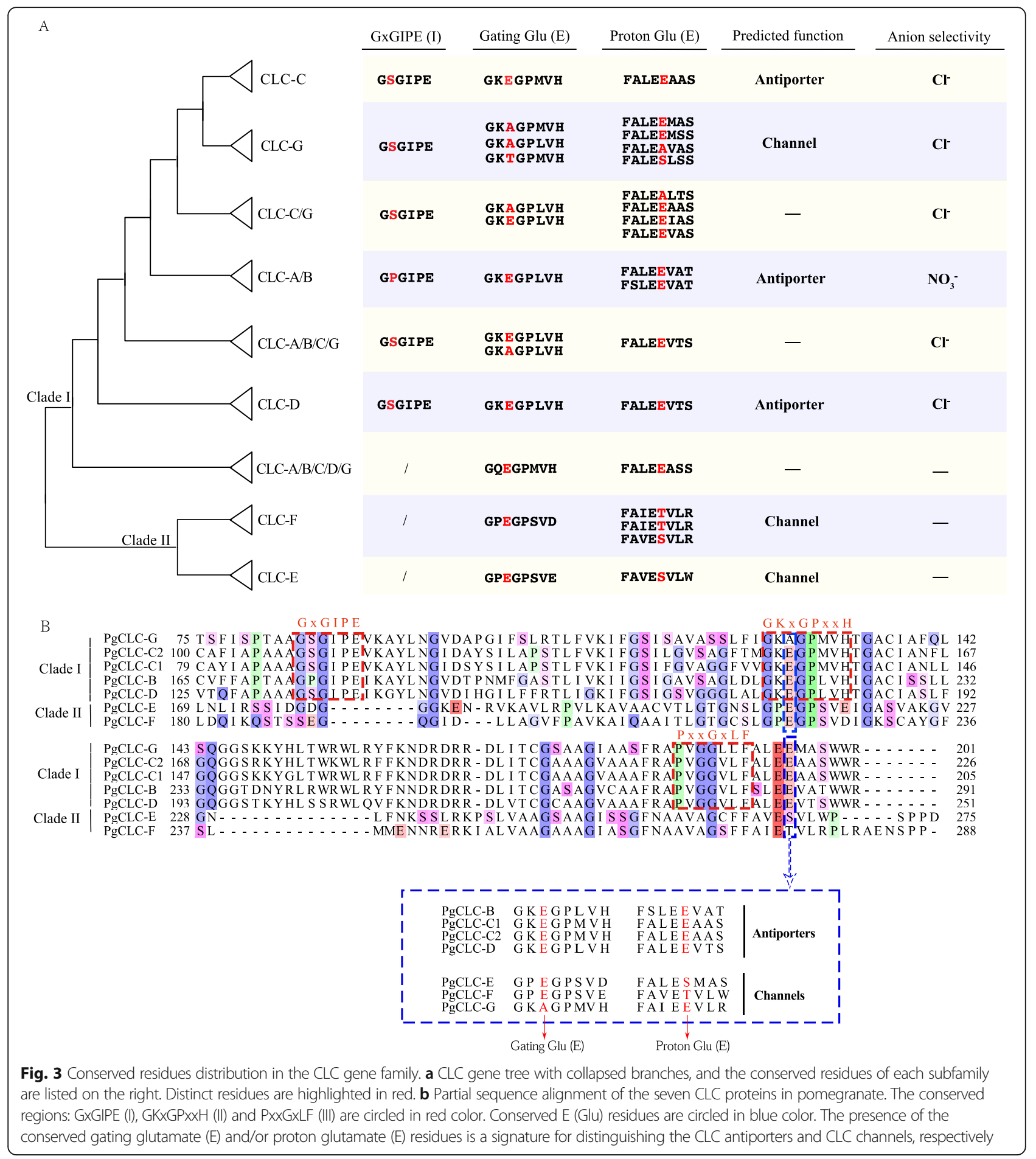

and total dry weight first increased and then decreased, reaching a peak at $100 \mathrm{mM}$ salinity level.

As shown in Fig. 4a, the contents of $\mathrm{Cl}^{-}$in pomegranate roots, stems and leaves significantly increased with the increasing concentration of $\mathrm{NaCl}(p<0.05)$. Under $300 \mathrm{mM}$ $\mathrm{NaCl}$ stress, the levels of $\mathrm{Cl}^{-}$in roots, stems and leaves increased 6.19, 5.29 and 7.42 times, compared with control, respectively. The contents of $\mathrm{Cl}^{-}$in plant tissues was ranked as leaf $>$ stem $>$ root. Compared to control, the $\mathrm{NO}_{3}{ }^{-}$contents in roots first increased and then decreased, with the highest value at $100 \mathrm{mM}$ salinity. However, the $\mathrm{NO}_{3}{ }^{-}$contents in stems and leaves had no obvious changes, except $\mathrm{NO}_{3}{ }^{-}$content in stem at $300 \mathrm{mM}$ salinity $(p<0.05)$. The $\mathrm{NO}_{3}{ }^{-}$contents in plant tissues was ranked 

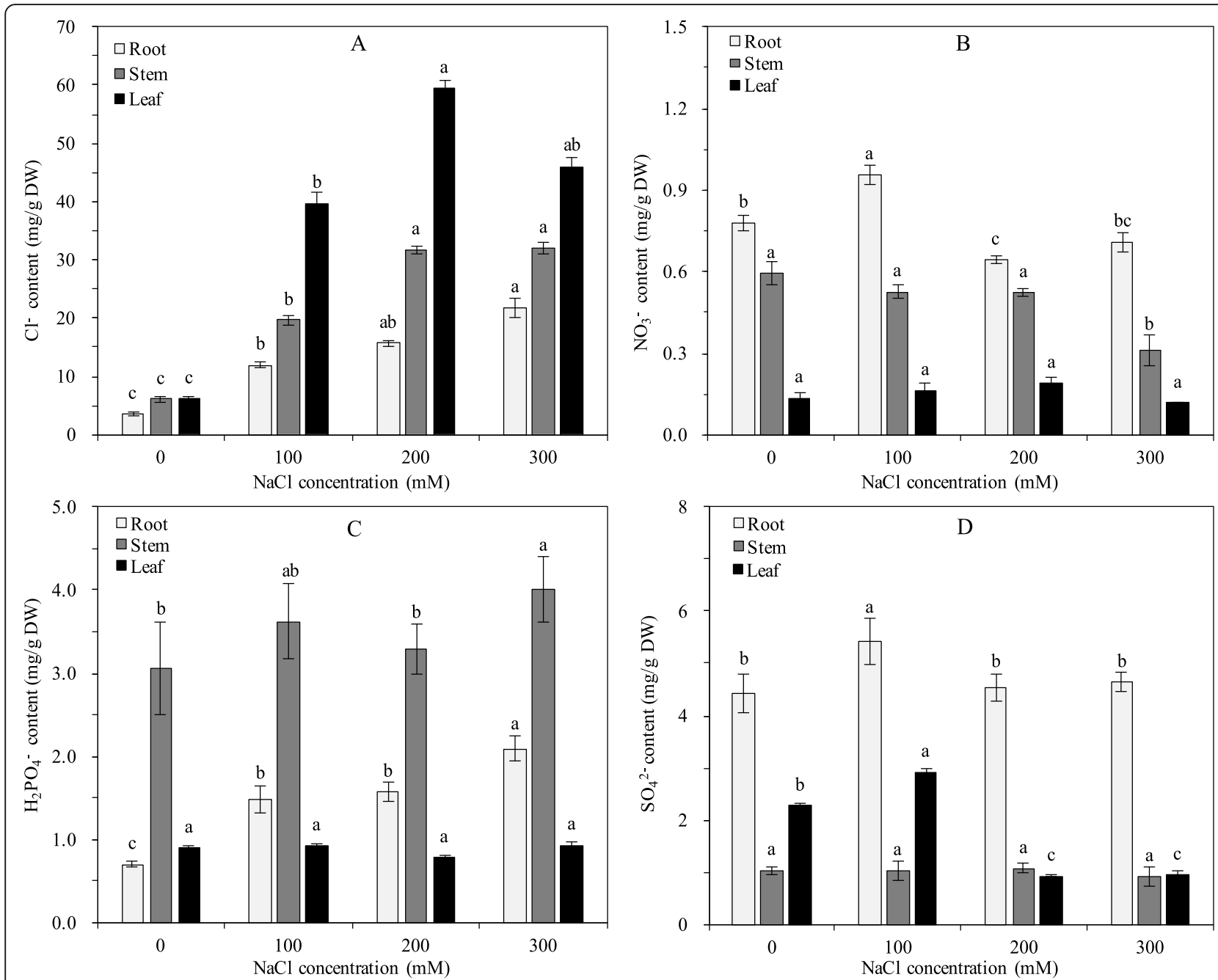

Fig. 4 The concentrations of $\mathrm{Cl}^{-}(\mathbf{a}), \mathrm{NO}_{3}{ }^{-}(\mathbf{b}), \mathrm{H}_{2} \mathrm{PO}_{4}^{-}(\mathbf{c})$, and $\mathrm{SO}_{4}{ }^{2-}$ (d) in pomegranate tissues under $\mathrm{NaCl}$ stress. The values are the means $\pm \mathrm{SE}$ of three replicates. Bars with different letters within each panel are significant differences at $p<0.05$ among different concentrations of salinity according to the Turkey's test

as root $>$ stem $>$ leaf (Fig. 4b). By contrast, the $\mathrm{H}_{2} \mathrm{PO}_{4}{ }^{-}$ contents in roots increased along with the increasing salinity, while no significant changes were observed in most leaf and stem samples $(p<0.05)$. Moreover, we found that $\mathrm{H}_{2} \mathrm{PO}_{4}{ }^{-}$was mainly accumulated in stems (Fig. 4c). For the $\mathrm{SO}_{4}{ }^{2-}$ contents, trends of first increasing and then decreasing in pomegranate roots and leaves were observed with peaks at $100 \mathrm{mM}$ salinity. As Fig. $4 \mathrm{~d}$ shown, $\mathrm{SO}_{4}{ }^{2-}$ mainly accumulated in roots, and the content of $\mathrm{SO}_{4}{ }^{2-}$ in leaves fell sharply under higher salinity (> $200 \mathrm{mM} \mathrm{NaCl})$.

Expression patterns of the $\mathrm{PgCLC}$ genes under $\mathrm{NaCl}$ stress To further investigate the expression patterns of the PgCLC genes, we performed the qRT-PCR analysis in pomegranate roots and leaves. The results showed that all the PgCLC genes had tissue-specific expression patterns, with high expression levels in leaves and low expression levels in roots (Fig. 5). Notably, when plants were subjected to salinity, the expression levels of all the tested $P g C L C s$ were up-regulated in pomegranate leaves, but were down-regulated or not obviously changed in roots $(p<0.01)$. For instance, the relative expression levels of $P g C L C-B, P g C L C-C 1, P g C L C-C 1$ and $P g C L C-D$ in leaves increased with the increasing salinity; meanwhile, those of $P g C L C-E, P g C L C-F$ and PgCLC-G in leaves significantly increased at high salinity $(200 \mathrm{mM})$. Also, the expression levels of PgCLC-B, PgCLC-F and PgCLC-G in roots decreased and those of $P g C L C-C 1, P g C L C-C 2, P g C L C-D$ and $P g C L C-E$ in roots first decreased at $100 \mathrm{mM}$ salinity level and then recovered slightly at $200 \mathrm{mM}$ and/or $300 \mathrm{mM}$ salinity levels (Fig. 5). Under $300 \mathrm{mM} \mathrm{NaCl}$ stress, the expression levels of $P g C L C-C 1, P g C L C-C 2$ and $P g C L C-F$ in leaves increased by more than 16 -fold relative to those of controls. 

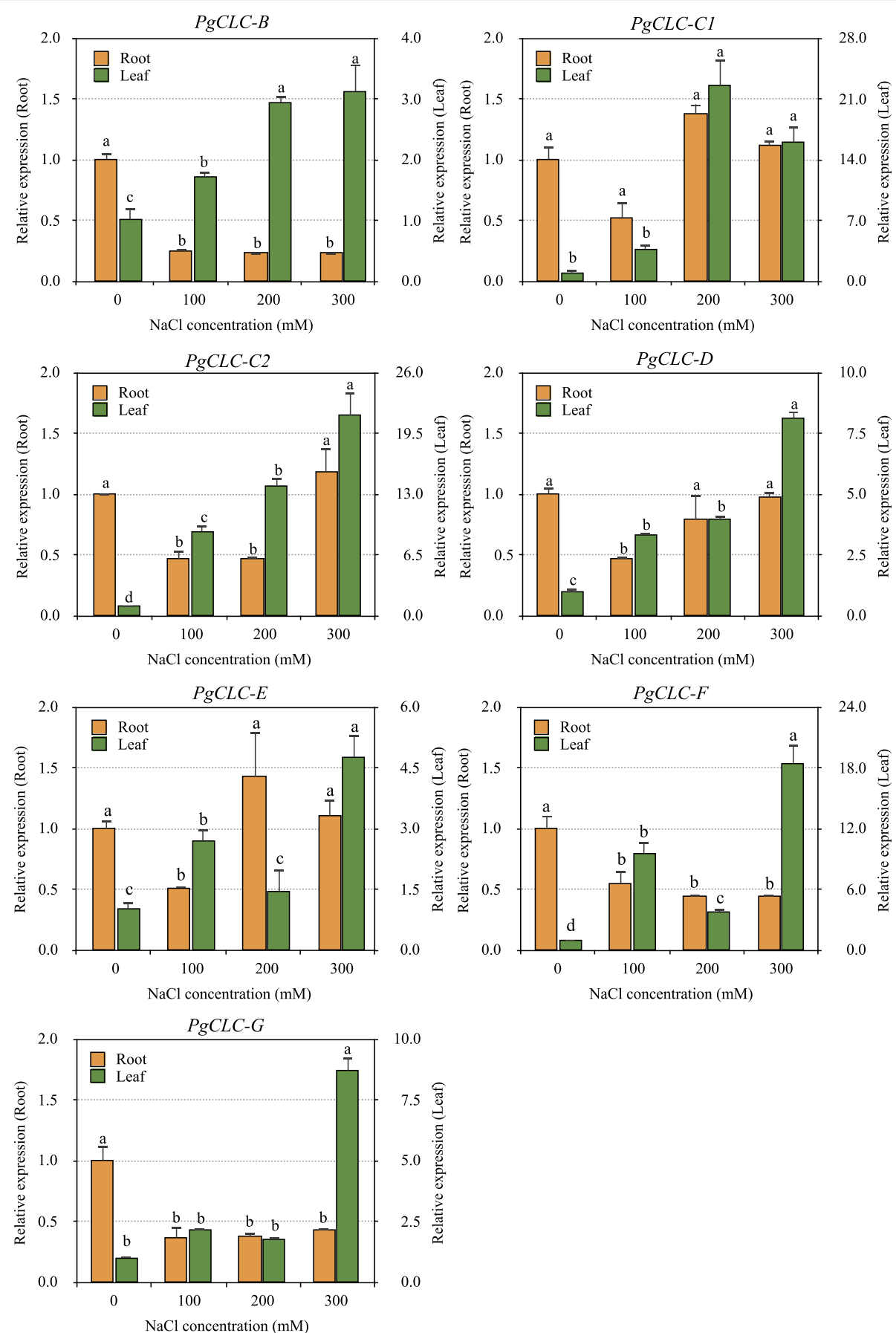

Fig. 5 qRT-PCR analysis of the CLC genes in pomegranate roots and leaves after 18 days of $\mathrm{NaCl}$ stress, the expressional levels are calculated by the $2^{-\Delta \Delta C T}$ method. Bars with different letters within each panel are significant differences at $p<0.05$ among different concentrations of salinity according to the Turkey's test

Correlation between the anion contents and expression levels of the $P g C L C$ genes

Correlation analysis showed that the PgCLC genes were positively correlated with each other (Fig. $6, p<0.05$ ). The $\mathrm{Cl}^{-}$contents had significantly positive correlations with $P g C L C-B, P g C L C-C 1, P g C L C-C 2$ and PgCLC-D, while the
$\mathrm{SO}_{4}{ }^{2-}$ content had significantly negative correlations with these genes. Meanwhile, the contents of $\mathrm{Cl}^{-}$and $\mathrm{SO}_{4}{ }^{2-}$ were negatively correlated with each other $(p<0.05)$. A significantly negative correlation between the $\mathrm{NO}_{3}{ }^{-}$content and the expression level of $\operatorname{PgCLC}-B$, and a significantly positive correlation between the $\mathrm{SO}_{4}{ }^{2-}$ were found. 


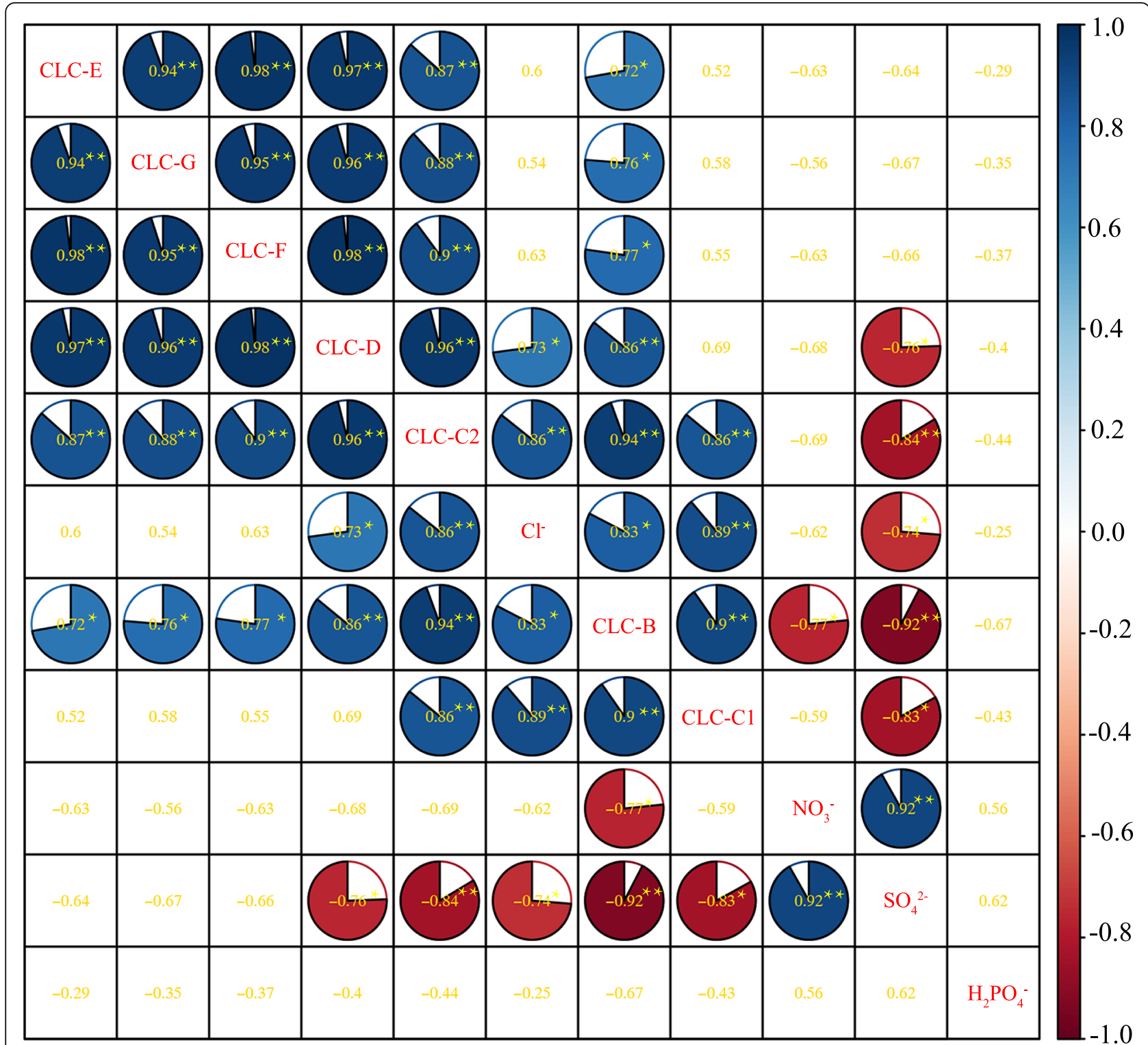

Fig. 6 Correlations between the expression levels of seven PgCLCs and the anion contents of pomegranate roots and leaves. The blue pie indicates a positive correlation, and the red pie indicates a negative correlation. The darker the color, the more significant the correlation. The gold numbers are correlation coefficients. ${ }^{* *}$ is highly significant at $p<0.01$ and * is significant at $p<0.05$

There was no significant relationship between the $\mathrm{H}_{2} \mathrm{PO}_{4}{ }^{-}$ content and the other indexes (Fig. 6). These findings suggested that accumulation of $\mathrm{Cl}^{-}, \mathrm{SO}_{4}{ }^{2-}$ and $\mathrm{NO}_{3}{ }^{-}$in pomegranate tissues was associated with the expression levels of the $P g C L C$ genes under salt stress.

\section{Discussion}

Identification of the CLC gene family in pomegranate

The CLC gene family is an evolutionarily well-conserved family, which has been found in prokaryotes and eukaryotes [14, 19]. CLC channels form two-pore homodimers with two monomers, and each monomer has its own pore through which $\mathrm{Cl}^{-}$and other anions $\left(\mathrm{HCO}_{3}{ }^{-}, \mathrm{I}^{-}\right.$, and $\mathrm{NO}_{3}{ }^{-}$) may be conducted $[14,38]$. CLC transporters and channels have regulatory functions when ATP, ADP, AMP, or adenosine are bound at the CBS domains [38]. In pomegranate, each CLCs contains one voltagegated CLC domain near the N-terminus and two CBS domains at the $\mathrm{C}$-terminus. The specific effect implies that individual CLC transporters and channels are sensitive to the cell's metabolic state $[14,27]$.

\section{Phylogenic relationships of the CLC gene family}

Numerous early whole-genome duplication (WGD) events in plants, including the gamma event shared by core-eudicots [39], the WGD event shared by 
angiosperms [40-42], and the seed-plant WGD event $[40,41]$, contribute to gene duplications. The diversity of gene copy numbers from different lineages (Fig. 1a) might be related to the rounds of WGD events shared with the taxon [43]. Based on the phylogenic analysis of the CLC gene family in 15 land plants, seven PgCLCs were divided into two clades, with clade I belonging to a eukaryotic branch and clade II belonging to a bacterial branch [32, 33]. The divergence of clade I and clade II might have occurred before the origin of land plants due to each clade consisting of taxa from embrophytes (Fig. 1). The CLCs topology was consistent with that of Arabidopsis [32, 33], tobacco [44], tea (Camellia sinensis) [24] and trifoliate orange [23]. Phylogenetic analysis also indicated multiple rounds of ancient gene expansion (Fig. 1). For example, the gene duplication between PgCLC-C1 and PgCLC-C2 (the red star in Fig. 1b) was supported by the duplication burst shared by core eudicots [45]. The gene duplication between the CLC-C and CLC-G subfamilies was due to one duplicate shared with angiosperms (the purple star in Fig. 1b) [45]. In the CLC-A/B subfamily, only one member PgCLC-B was identified in pomegranate. While there were two members from Arabidopsis and Eutrema due to a specific gene duplication shared by plants of Brassicaceae [46]. Our phylogenetic analyses also found a gene expansion in seed plants, with a gene birth from an ancient gene duplication (the green star in Fig. 1b) and a subsequent gene death. The CLC-A/B/C/G subfamily (Fig. 1) exhibited a gene loss event in gymnosperms after experiencing the seed-plant WGD event [40, 41] despite the fact that the absence of the gene might have resulted from the putative incompleteness of the genome assembly and annotation. Recent phylogenetic studies have also found land plant-scale gene birth and expansion, such as in the CYP75 gene family [43] and GH28 gene family [40].

Additionally, the distributions of conserved motifs and conserved regions were consistent with the phylogenetic relationships (Fig. 2). Three highly conserved regions of the CLC gene family, GxGIPE (I), GKxGPxxH (II) and PxxGxLF (III) were shared by the members of clade I, whereas they were not shared by the members of clade II. This finding indicated that the divergence of clades I and clade II might be due to the presence of these conserved regions (Fig. 2c). Our study also found that the $x$ residue in the conserved region (I) of the CLC-A/B subfamily was P [proline, Pro] (Fig. 3; Fig. S2), which preferentially transports $\mathrm{NO}_{3}{ }^{-}$[25], while that of the CLC-C, CLC-D and CLC-G subfamily was S [serine, Ser] (Fig. 3; Fig. S2), which preferentially transports $\mathrm{Cl}^{-}$[25]. Thus, PgCLC-B was likely a $\mathrm{NO}_{3}{ }^{-} / \mathrm{H}^{+}$exchanger that mainly transported $\mathrm{NO}_{3}^{-}$rather than $\mathrm{Cl}^{-}[21,34]$, while PgCLC-C, PgCLC-D and PgCLC-G might have high affinity for $\mathrm{Cl}^{-}[21,34]$. A presence of the gating glutamate $(\mathrm{E})$ residue and proton glutamate $(\mathrm{E})$ residue was signature for CLC antiporters [26, 27]. However, if one or both of the Glu (E) residues were substituted by any other amino acids in the conserved region, the CLC proteins might exhibit CLC channels activity [27]. Therefore, we assumed that PgCLC-B, PgCLC-C1, PgCLC-C2 and PgCLC-D were CLC antiporters and PgCLC-E, PgCLC-F and PgCLC-G were CLC channels. Our results were in line with the findings in Arabidopsis [26, 27].

\section{PgCLCs played roles in response to $\mathrm{NaCl}$ stress}

As an essential micronutrient for plants, $\mathrm{Cl}^{-}$is beneficial for plants at low concentrations in media $[4,5]$. However, high salinity (mainly $\mathrm{NaCl}$ ) may cause a perturbation of $\mathrm{Na}^{+}$and $\mathrm{Cl}^{-}$at both the cellular and whole plant levels, which affects the uptake and transport of other mineral ions, such as $\mathrm{K}^{+}, \mathrm{Ca}^{2+}, \mathrm{Mg}^{2+}, \mathrm{H}_{2} \mathrm{PO}_{4}{ }^{-}$, $\mathrm{NO}_{3}{ }^{-}$and $\mathrm{SO}_{4}{ }^{2-}[47,48]$. In this study, we focused on the anion accumulation in pomegranate tissues. CLC proteins are expressed on the cell membrane and conduct $\mathrm{Cl}^{-}$or other anions, such as $\mathrm{HCO}_{3}{ }^{-}, \mathrm{I}^{-}$, and $\mathrm{NO}_{3}{ }^{-}$ [14-17]. Compared with the controls, the expression levels of PgCLCs were up-regulated in leaves and downregulated or not significantly changed in roots $(p<0.01)$. The tissue-specific expression of seven PgCLCs indicated different mechanisms of transporting anions in pomegranate roots and leaves. Our study found that the $\mathrm{Cl}^{-}$ contents in pomegranate tissues sharply increased with an order of leaf $>$ stem $>$ root (Fig. 4a), indicating a relatively strong ability for pomegranate to transport and accumulate toxic ions in the acrial parts [49]. In leaves, the high expression levels of $P g C L C s$ suggested the inclusion of $\mathrm{Cl}^{-}$into leaf cells or organelles. Individually, the expression levels of three antiporters $P g C L C-C 1, P g C L C$ $C 2$ and $P g C L C-D$ were significantly positive with the $\mathrm{Cl}^{-}$ content, which might be contributed to the sequestration of $\mathrm{Cl}^{-}$into the leaf vacuoles $[28,50]$. However, the low expression levels of PgCLCs in roots suggested the exclusion of $\mathrm{Cl}^{-}$from root cells. The recovery of $\mathrm{PgCLC}$ $C 1, P g C L C-C 2$ and $P g C L C-D$ in roots were contributed to the sequestration of $\mathrm{Cl}^{-}$into the root vacuoles at high salinity levels $[28,50]$. Therefore, $P g C L C s$ were supposed to alleviate the deleterious effects of $\mathrm{Cl}^{-}$via excluding the $\mathrm{Cl}^{-}$from root cells and sequestrating $\mathrm{Cl}^{-}$into the leaf vacuoles $[28,50]$. Similarly, some halophytes prefer to transport and accumulate detrimental ions in the acrial parts under salt stress $[51,52]$. On the other hand, under moderate salinity $(\leq 200 \mathrm{mM} \mathrm{NaCl})$, the low expression levels of three $\mathrm{Cl}^{-}$channels PgCLC-E, PgCLC-F and $P g C L C-G$ in leaves (Fig. 5), suggested the capacity for pomegranate to inhibit the $\mathrm{Cl}^{-}$influx into cells or organelles [3, 33].

Also, the $\mathrm{NO}_{3}{ }^{-}$contents of pomegranate roots first increased and then decreased, and that of leaves not 
changed under salt stress (Fig. 4b, d). The increase of the $\mathrm{Cl}^{-}$content was concomitant with the decrease of the $\mathrm{NO}_{3}{ }^{-}$content in pomegranate tissues, which could be due to the antagonism between $\mathrm{Cl}^{-}$and $\mathrm{NO}_{3}{ }^{-}$[53]. The expression level of $\operatorname{PgCLC}-B$ (a $\mathrm{NO}_{3}{ }^{-} / \mathrm{H}^{+}$exchanger) [21, 34], was significantly positive correlated with the $\mathrm{Cl}^{-}$content, and significantly negative correlated with the $\mathrm{NO}_{3}{ }^{-}$ content $(p<0.05)$. These results suggested that the decreased uptake of $\mathrm{NO}_{3}{ }^{-}$in roots might be due to the inhibition of $P g C L C-B$ activity under salt stress $[21,34]$. The inhibition of nitrogen uptake was also associated with nitrate transporter (NRTs) [54, 55]. Meanwhile, the increased expression level of $P g C L C-B$ in leaves indicated an acceleration of transporting $\mathrm{NO}_{3}{ }^{-}$into leaves to mitigate the nitrogen deficiency [34]. Teakle et al. [6] reported that the increased concentration of $\mathrm{NO}_{3}{ }^{-}$in media reduced the $\mathrm{Cl}^{-}$content in leaves and then mitigated the foliar salt damage, the $\mathrm{NO}_{3}{ }^{-} / \mathrm{Cl}^{-}$was contributed to the plant salt resistance $[8,13]$. In pomegranate, it was observed that a low ratio of $\mathrm{NO}_{3}{ }^{-} / \mathrm{Cl}^{-}$might cause a reduction in growth [56] (data not showed).

In a word, these findings suggested that the PgCLC genes played important roles in uptake and transport of $\mathrm{Cl}^{-}$and $\mathrm{NO}_{3}{ }^{-}$in pomegranate tissues under salt stress $[15-17,28]$. While the accumulation pattern of $\mathrm{SO}_{4}{ }^{2-}$ was associated with the other genes, such as sulfate transporters [57]. Wei et al. [23] found that PtrCLC genes were dramatically induced in response to $\mathrm{NaCl}$ stress, and PtrCLC6 showed a leaf-specific expression pattern in trifoliate orange. Zhang et al. [44] observed that all of the expressed $N t C L C$ genes had a low expression level in tobacco roots under salt stress. Our findings are consistent with these reports. In addition, the functional characterization of each $P g C L C$ genes need to further study.

\section{Conclusions}

In this study, we identified and characterized seven $C L C$ genes in pomegranate. Phylogenetic analysis indicated that the PgCLCs were divided into two distinct clades, with a similar distribution of conserved motifs and regions in the members of each clade. In pomegranate, the $P g C L C$ genes displayed a tissue-specific expression pattern, with the high expression levels in leaves and the low expression levels in roots under salt stress. PgCLCs were supposed to play important roles in balancing of $\mathrm{Cl}^{-}$and $\mathrm{NO}_{3}{ }^{-}$in pomegranate tissues under salt stress. Our study provides the basis for the further functional characterization of the $P g C L C$ genes.

\section{Methods}

\section{Identification of the CLC gene family in pomegranate}

A Hidden Markov Model (HMM) profile of the voltagegated chloride channel (Voltage-gate CLC) domain
(Accession no. PF00654) was employed to identify the putative CLC proteins from genome sequences using the software HMMER v3.1b1 [58] accorrding to the methods of Zhang et al. [43] with a cut-off E-value of $\leq 1 \mathrm{e}^{-10}$. To construct a representative phylogeny across land plants, ten angiosperms (eight core eudicots and two monocots), two gymnosperms and three bryophytes were selected, including Arabidopsis thaliana, Citrus sinensis, Eucalyptus grandis, Eutrema salsugineum, Glycine max, Populus euphratica, Punica granatum, and Vitis vinifera as the core eudicots; Oryza sativa and Zostera marina as monocots; Ginkgo biloba and Pinus taeda as gymnosperms; and Marchantia polymorpha, Selaginella moellendorffii and Sphagnum fallax as bryophytes. Seven CLC proteins from Arabidopsis thaliana were obtained from the Arabidopsis Information Resource (TAIR) (http://www.arabidopsis.org/). The genome sequences of 14 other species were downloaded from URLs (Table S1). Firstly, all the putative CLC proteins were identified from the genomes of the 14 species. Subsequently, the CLC candidates were manually curated, and the nonredundant CLC proteins were further analyzed using the NCBI Conserved Domain Database (CDD, http://www.ncbi.nlm.nih.gov/cdd/) and SMART programs (http://smart.embl-heidelberg.de/) to confirm the presence of the Voltage-gate CLC domain. The theoretical isoelectric point $(\mathrm{pI})$, molecular weight $(\mathrm{Mw})$ and grand average of hydrophobicity (GRAVY) of seven PgCLC proteins were predicted using the Prot-Param tool (http://web.expasy.org/protparam/). The number of transmembrane helices (TMHs) was predicted using TMHMM Server v. 2.0 (http://www.cbs.dtu.dk/services/ TMHMM/) and TMpred (https://embnet.vital-it.ch/software/TMPRED_form.html).

\section{Phylogenetic analysis of CLC gene family}

To estimate the origin and divergence of CLC genes, an maximum likelihood (ML) tree of these genes was reconstructed using iQ-TREE and used to map on a species tree of land-plants, which is a part of the tree of life as inferred in the OneKP project [40], by using the methods in Zhang et al [59]. All of the puative CLC proteins were aligned using MUSCLE v3.8.31 [60] with the 'auto' setting. To improve the valid phylogeny signals, the low-quality alignment regions and incorrect sequences with apparent splice variants were removed [61]. Finally, a total of 113 putative CLC candidates were retained, including seven PgCLCs (Table S2). The conserved blocks were retained by Gblocks v0.91b [62], and then, phylogenetic analysis was preformed using iQTREE v2 [63] with the LG + R6 model, 1000 bootstraps, and the Shimodaira-Hasegawa-like aLRT (SH-aLRT) test. Putative functional homologs were identified from a gene clade that contained the query gene from 
Arabidopsis and was likely derived from an ancestral gene from land plants [59].

Conserved motifs and residues prediction of CLC proteins The conserved motifs and regions of all CLC proteins were predicted by the MEME tool (http://meme-suite.org/ tools/meme). The maximum number of motifs was set to 10 , and the optimum motif width was $\geq 6$ and $\leq 50$. Three conserved regions (GxGIPE (I), GKxGPxxH (II) and PxxGxLF (III)) of the CLC gene family were searched by the MAST tool (http://meme-suite.org/tools/mast) with a sequence threshold $\leq 30$ and an E-value $\leq 1 \mathrm{e}^{-10}$ for motifs. Multiple sequence alignment of CLCs was performed by Clustal X v2.0 [64] and visualized by Jalview v1.0 [65].

\section{Plant materials and growth conditions}

Pomegranate cv. 'Taishanhong' cuttings (one-year-old, collected from Pomegranate repository of Nanjing Forestry University. China) were planted in a phytotron for six months, with a $28 / 22{ }^{\circ} \mathrm{C}$ day/night temperature, $60 \%$ humidity and $14 \mathrm{~h}$ light $/ 10 \mathrm{~h}$ dark photoperiod. Hoagland's nutrient solution [66] was supplied at the beginning of the experiment. A total of 24 pots (one plant per plot) were arranged in a completely randomized 3 blocks, and 8 pots per block, and every 2 pots were designed as a biological replicate. All plants were fertigated with half-strength Hoagland's solution containing 0 (control), 100, 200, or $300 \mathrm{mM} \mathrm{NaCl}$ every six days, respectively. A saucer was placed under the containers to keep the soil moist. According to our previous study, after 18 days of treatments, the salt damage on pomegranate plant were significant [3]. Therefore, we harvested all plants separately to collect roots, stems, and leaves after $18 \mathrm{~d}$.

\section{Anion content measurement}

The dry weights of pomegranate roots, stems and leaves were determined after drying in a heating oven at $75^{\circ} \mathrm{C}$ for $48 \mathrm{~h}$. Dry samples were finely milled to pass through a 40 -mesh sieve. Then $0.4 \mathrm{~g}$ of samples were treated with $50 \mathrm{~mL}$ of deionized water for $1 \mathrm{~h}$ in an ultrasonic extractor at room temperature, and then the obtained extracts were used to determine the contents of $\mathrm{Cl}^{-}, \mathrm{NO}_{3}{ }^{-}$, $\mathrm{H}_{2} \mathrm{PO}_{4}{ }^{-}$, and $\mathrm{SO}_{4}{ }^{2-}$ using an ion chromatography (ICS900 ion chromatographic system; AS4A-SC ionexchange column, CD M-II electrical conductivity detector, mobile phase: $\mathrm{Na}_{2} \mathrm{CO}_{3} / \mathrm{NaHCO}_{3}=1.7 / 1.8 \mathrm{mM}$; Dionex, Sunnyvale, USA) [67].

\section{Expression levels of $P g C L C s$ by quantitative real-time PCR (qRT-PCR)}

Total RNA was extracted from fresh root and leaf samples using the BioTeke plant total RNA extraction kit
(BioTeke Corporation, Beijing, China) according to the manufacturer's instructions. First-strand cDNA was prepared using a reverse transcription kit-PrimeScript ${ }^{\mathrm{TM}} \mathrm{RT}$ reagent Kit with gDNA Eraser (TaKaRa Bio Tech Co., Ltd., Beijing, China). The primers of seven PgCLCs were designed with NCBI primer-BLAST (Table S3). Realtime RT-PCR (qRT-PCR) was performed using a 7500 fast Real-Time PCR system (Applied Biosystems, CA, USA) with three biological and three technical replicates for each cDNA sample, and the results were quantitatively analyzed by the $2^{-\Delta \Delta C T}$ method [68]. Each reaction was carried out in a final volume of $20 \mu \mathrm{L}$, containing $10 \mu \mathrm{L}$ of TB Green Premix Ex Taq, $0.4 \mu \mathrm{L}$ of ROX Reference Dye II, $0.8 \mu \mathrm{L}$ of upstream/downstream primers, $1 \mu \mathrm{L}$ of cDNA template and $7 \mu \mathrm{L}$ of $\mathrm{ddH}_{2} \mathrm{O}$. The PCR thermal cycler was set as follows: pre-denaturation at $95^{\circ} \mathrm{C}$ for $30 \mathrm{~s} ; 40$ cycles of $95^{\circ} \mathrm{C}$ for $5 \mathrm{~s}$ and $60^{\circ} \mathrm{C}$ for 34 $\mathrm{s}$; the dissociation stage was set as follows: $95^{\circ} \mathrm{C}$ for $15 \mathrm{~s}$, $60{ }^{\circ} \mathrm{C}$ for $60 \mathrm{~s}$ and $95^{\circ} \mathrm{C}$ for $15 \mathrm{~s}$. Pomegranate PgActin was used as an internal reference gene.

\section{Data analysis}

All data of the anion contents and qRT-PCR were analyzed with one-way ANOVA, and multiple comparisons were evaluated with the Turkey's test $(p<0.05)$ using the SPSS program (Version 19.0. Chicago, IL, USA) based on the values of three complete randomized blocks. The correlation among variables was analyzed based on the ion content and expressional level of PgCLCs and visualized by a 'corrplot' package in $\mathrm{R}$ [69].

\section{Supplementary Information}

The online version contains supplementary material available at https://doi. org/10.1186/s12870-020-02771-z.

Additional file 1: Table S1. A summary of 15 species for phylogenetic analysis and their genomic sources. Table S2. List of CLC proteins used for constructing the phylogenetic tree. Table S3. Primers used in qRTPCR analysis for PgCLCS. Table S4. Dry weights of pomegranate cuttings under $\mathrm{NaCl}$ stress. (XLS $67 \mathrm{~kb}$ )

Additional file 2: Fig. S1. Phylogenetic relationship and conserved motifs of the CLC gene family in land plants. Fig. S2. Multiple sequence alignment of all the CLC proteins from 15 species.

\section{Abbreviations}

CLC: Chloride channel; CBS: Cystathionine Beta Synthase; Glu: glutamate; pl: Theoretical Isoelectric Point; Mw: Molecular Weight; GRAVY: Grand Average of Hydrophobicity; TMHs: Transmembrane Helices; ML: Maximum Likelihood; WGD: Whole-genome Duplication; OneKP preoject: One Thousand Plant Project; SH-aLRT: Shimodaira-Hasegawa-like aLRT; qRTPCR: Quantitative real-time polymerase chain reaction

Acknowledgements

Not applicable.

Authors' contributions

$\mathrm{CL}$ and $\mathrm{YZ}$ analyzed and interpreted the phylogenetic analysis. $Y Z$ and JD performed the expression level examination of the stressed plants. $C L$ was a 
major contributor in determining the ion content, analyzing data and writing the manuscript, and $X Z$ and $Z Y$ revised the manuscript. All authors read and approved the final manuscript.

\section{Funding}

This work was supported by the Initiative Project for Talents of Nanjing Forestry University (GXL2014070, GXL2018032), the Doctorate Fellowship Foundation of Nanjing Forestry University, and the Priority Academic Program Development of Jiangsu High Education Institutions (PAPD), the National Natural Science Foundation of China (31901341), the Natural Science Foundation of Jiangsu Province (BK20180768). These funding bodies took part in the design of the study and collection, analysis, and interpretation of data, and the writing of the manuscript, as well as in the open access payment.

\section{Availability of data and materials}

The datasets supporting the conclusions of this article are included within the article (and its additional files).

\section{Ethics approval and consent to participate}

Not applicable.

\section{Consent for publication}

Not applicable.

\section{Competing interests}

The authors declare that they have no competing interests.

\section{Received: 6 August 2020 Accepted: 2 December 2020}

Published online: 11 December 2020

\section{References}

1. Holl D, Hatib K, Bar-Ya'Akov I. Pomegranate: botany, horticulture, breeding. Hortic Rev. 2009;35(2):127-91.

2. Bhantana P, Lazarovitch N. Evapotranspiration, crop coefficient and growth of two young pomegranate (Punica granatum L.) varieties under salt stress. Agric Water Manag. 2010;97(5):715-22.

3. Liu C, Yan M, Huang $X$, Yuan Z. Effects of $\mathrm{NaCl}$ stress on growth and ion homeostasis in pomegranate tissues. Eur J Hortic Sci. 2020;85(1):42-50.

4. Marschner P. Marschner's mineral nutrition of higher plants. 3rd ed. Australia: Academic press; 2012.

5. White PJ, Broadley MR. Chloride in soils and its uptake and movement within the plant: a review. Ann Bot. 2001;88(6):967-88.

6. Teakle NL, Tyerman SD. Mechanisms of $\mathrm{Cl}^{-}$transport contributing to salt tolerance. Plant Cell Environ. 2010;33(4):566-89.

7. Karaivazoglou NA, Papakosta DK, Divanidis S. Effect of chloride in irrigation water and form of nitrogen fertilizer on Virginia (flue-cured) tobacco. Field Crops Res. 2005:92(1):61-74.

8. Munns R, Tester M. Mechanisms of salinity tolerance. Annu Rev Plant Biol. 2008;59(1):651-81.

9. Tregeagle JM, Tisdall JM, Tester M, Walker RR, Barrettlennard EG, Setter TL. $\mathrm{Cl}^{-}$uptake, transport and accumulation in grapevine rootstocks of differing capacity for $\mathrm{Cl}^{-}$exclusion. Funct Plant Biol. 2010;37(7):665-73.

10. Moya JL. Chloride absorption in salt-sensitive Carrizo citrange and salttolerant Cleopatra mandarin citrus rootstocks is linked to water use. J Exp Bot. 2003;54(383):825-33

11. Luo QY, Bing-Jun YU, Liu YL. Stress of $\mathrm{Cl}^{-}$is stronger than that of $\mathrm{Na}^{+}$on Glycine max seedlings under NaCl stress. J Integr Agric. 2002;1(12):1404-9.

12. Zhang XK, Zhou QH, Cao JH, Yu BJ. Differential $\mathrm{Cl}^{-}$/salt tolerance and $\mathrm{NaCl}$ induced alternations of tissue and cellular ion fluxes in Glycine max, Glycine soja and their hybrid seedlings. J Agronomy Crop Sci. 2011;197(5):329-39.

13. Apse MP, Blumwald E. $\mathrm{Na}^{+}$transport in plants. FEBS Lett. 2007;581(12):224754.

14. Lu SN, Wang JY, Chitsaz F, Derbyshire MK, Geer RC, Gonzales NR, et al. CDD/ SPARCLE: the conserved domain database in 2020. Nucleic Acids Res. 2020; 48(D1):D265-8.

15. Miller AJ, Fan X, Orsel M, Smith SJ, Wells DM. Nitrate transport and signalling. J Exp Bot. 2007:58(9):2297.

16. Amtmann A, Armengaud $P$, Salt DE, Williams L. Effects of $N, P, K$ and $S$ on metabolism: new knowledge gained from multi-level analysis. Curr Opin Plant Biol. 2009;12(3):275-83.
17. Gojon A, Nacry P, Davidian JC. Root uptake regulation: a central process for NPS homeostasis in plants. Curr Opin Plant Biol. 2009;12(3):328.

18. Jentsch TJ, Steinmeyer K, Schwarz G. Primary structure of Torpedo marmorata chloride channel isolated by expression cloning in Xenopus oocytes. Nature. 1990;348(6301):510-14.

19. Jentsch TJ. CLC chloride channels and transporters: from genes to protein structure, pathology and physiology. Crit Rev Biochem Mol. 2008;43(1):3-36.

20. Lurin C, Geelen D, Barbierbrygoo H, Guern J, Maurel C. Cloning and functional expression of a plant voltage-dependent chloride channel. Plant Cell. 1996;8(4):701-11.

21. De Angeli A, Monachello D, Ephritikhine G, Frachisse J, Thomine S, Gambale F, et al. The nitrate/proton antiporter AtCLCa mediates nitrate accumulation in plant vacuoles. Nature. 2006:442(7105):939-42.

22. Nakamura A, Fukuda A, Sakai S, Tanaka Y. Molecular cloning, functional expression and subcellular localization of two putative vacuolar voltage-gated chloride channels in rice (Oryza sativa L.). Plant Cell Physiol. 2006;47(1):32-42.

23. Wei QJ, Gu QQ, Wang NN, Yang CQ, Peng S. Molecular cloning and characterization of the chloride channel gene family in trifoliate orange. Biol Plantarum. 2015:59(4):645-53.

24. Xing AQ, Ma YC, Wu ZC, Nong SH, Zhu JJ, Sun H, et al. Genome-wide identification and expression analysis of the CLC superfamily genes in tea plants (Camellia sinensis). Funct Integr Genomic. 2020;20:497-508.

25. Zifarelli G, Pusch M. CLC transport proteins in plants. FEBS Lett. 2010;584(10): 2122-7.

26. Lisal J, Maduke M. Proton-coupled gating in chloride channels. Philos T Roy Soc B. 2009:364(1514):181-7.

27. Accardi A, Picollo A. CLC channels and transporters: proteins with borderline personalities. Biochim Biophys Acta. 2010;1798(8):1457-64.

28. Jossier M, Kroniewicz L, Dalmas F, Le TD, Ephritikhine G, Thomine S, et al. The Arabidopsis vacuolar anion transporter, $\operatorname{AtCLCC}$, is involved in the regulation of stomatal movements and contributes to salt tolerance. Plant J. 2010;64(4):563-76

29. Wei QJ, Liu YZ, Zhou GF, Li QH, Yang CQ, Peng S. Overexpression of CsCLCC, a chloride channel gene from Poncirus trifoliata, enhances salt tolerance in Arabidopsis. Plant Mol Biol Rep. 2013;31(6):1548-57.

30. Jentsch TJ, Michael P. CLC chloride channels and transporters: structure, function, physiology, and disease. Physiol Rev. 2018;98(3):1493-590.

31. Guo W, Zuo Z, Cheng X, Sun J, Li H, Li L, et al. The chloride channel family gene CLCd negatively regulates pathogen-associated molecular pattern (PAMP)-triggered immunity in Arabidopsis. J Exp Bot. 2014;65(4):1205-15.

32. Barbierbrygoo HLN, Angeli AD, Filleur S, Frachisse JM, Gambale F, Thomine $\mathrm{SB}$, et al. Anion channels/transporters in plants: from molecular bases to regulatory networks. Annu Rev Plant Biol. 2011;62(62):25-51.

33. Marmagne A, Vinaugerdouard M, Monachello D, De Longevialle AF, Charon C, Allot $\mathrm{M}$, et al. Two members of the Arabidopsis CLC (chloride channel) family, AtCLCe and AtCLCf, are associated with thylakoid and Golgi membranes, respectively. J Exp Bot. 2007:58(12):3385-93.

34. Fechtbartenbach JVD, Bogner M, Dynowski M, Ludewig U. CLC-b-mediated $\mathrm{NO}_{3}{ }^{-} / \mathrm{H}^{+}$exchange across the tonoplast of Arabidopsis vacuoles. Plant Cell Physiol. 2010;51(6):960-8.

35. Tam NC, Astrid A, Mathieu J, Sylvain D, Sébastien T, Sophie F. Characterization of the chloride channel-like, AtCLCg, involved in chloride tolerance in Arabidopsis thaliana. Plant Cell Physiol. 2016:57(4):764-75.

36. Wei P, Wang L, Liu A, Yu B, Lam HM. GmCLCl confers enhanced salt tolerance through regulating chloride accumulation in soybean. Front Plant Sci. 2016;7(113):1082

37. Wei P, Che B, Shen L, Cui Y, Wu S, Cheng C, et al. Identification and functional characterization of the chloride channel gene, GSCLC-c2 from wild soybean. BMC Plant Biol. 2019;19(1):1-15.

38. Elgebali S, Mistry J, Bateman A, Eddy SR, Luciani A, Potter SC, et al. The Pfam protein families database in 2019. Nucleic Acids Res. 2019:47(D1):D427-32.

39. Jaillon O, Aury J, Noel B, Policriti A, Clepet C, Casagrande A, et al. The grapevine genome sequence suggests ancestral hexaploidization in major angiosperm phyla. Nature. 2007:449(7161):463-7.

40. Initiative OTPT. One thousand plant transcriptomes and the phylogenomics of green plants. Nature. 2019;574(7780):679-85.

41. Jiao Y, Wickett NJ, Ayyampalayam S, Chanderbali AS, Landherr L, Ralph PE, et al. Ancestral polyploidy in seed plants and angiosperms. Nature. 2011; 473(7345):97-100

42. Genome A. The Amborella Genome and the evolution of flowering plants Science. 2013;342(6165):1241089. 
43. Zhang TK, Liu CY, Huang XB, Zhang HY, Yuan ZH. Land-plant phylogenomic and pomegranate transcriptomic analyses reveal an evolutionary scenario of CYP75 genes subsequent to whole genome duplications. J Plant Biol. 2019;62(1):48-60.

44. Hui Z, Jin J, Jin L, Li Z, Xu G, Ran W, et al. Identification and analysis of the chloride channel gene family members in tobacco (Nicotiana tabacum). Gene. 2018;676:56-64.

45. Ren R, Wang HF, Guo CC, Zhang N, Zeng L, Chen YM, et al. Wide-spread whole genome duplications contribute to genome complexity and species diversity in angiosperms. Mol Plant. 2018;11(3):414-28.

46. Barker MS, Vogel H, Schranz ME. Paleopolyploidy in the Brassicales: analyses of the cleome transcriptome elucidate the history of genome duplications in Arabidopsis and other Brassicales. Genome Biol Evol. 2009;1(1):391-9.

47. Silva EN, Silveira JA, Rodrigues CR, Viégas RA. Physiological adjustment to salt stress in Jatropha curcas is associated with accumulation of salt ions, transport and selectivity of $\mathrm{K}^{+}$, osmotic adjustment and $\mathrm{K}^{+} / \mathrm{Na}^{+}$homeostasis. Plant Biol. 2015;17(5):1023-9.

48. Ibrahim $\mathrm{H}$. Tolerance of two pomegranates cultivars (Punica granatum L.) to salinity stress under hydroponic culture conditions. J Basic Appl Scientific Res. 2016;6(4):38-46.

49. Munns R. Comparative physiology of salt and water stress. Plant Cell Environ. 2002;25(2):239-50.

50. Zhang HW, Zhao FG, Tang RJ, Yu YX, Song JL, Wang Y, et al. Two tonoplast MATE proteins function as turgor-regulating chloride channels in Arabidopsis. P Natl Acad Sci USA. 2017;114(10):E2036-45.

51. Flowers TJ, Colmer TD. Salinity tolerance in halophytes. New Phytol. 2008; 179(4):945-63.

52. Orsini F, Accorsi M, Gianquinto G, Dinelli G, Antognoni F, Carrasco KBR, et al. Beyond the ionic and osmotic response to salinity in Chenopodium quinoa: functional elements of successful halophytism. Funct Plant Biol. 2011;38(10): 818-31.

53. Abdelgadir EM, Oka M, Fujiyama $\mathrm{H}$. Nitrogen nutrition of rice plants under salinity. Biol Plantarum. 2005:49(1):99-104.

54. Wang $H$, Zhang M, Guo R, Shi D, Liu B, Lin X, et al. Effects of salt stress on ion balance and nitrogen metabolism of old and young leaves in rice (Oryza sativa L.). BMC Plant Biol. 2012;12(1):194.

55. Kiba T, Feria-Bourrellier AB, Lafouge F, Lezhneva L, Boutet-Mercey S, Orsel M, et al. The Arabidopsis nitrate transporter NRT2.4 plays a double role in roots and shoots of nitrogen-starved plants. Plant Cell. 2012;24(1):245-58.

56. Grattan S, Grieve C. Salinity - mineral nutrient relations in horticultural crops. Sci Hortic-Amsterdam. 1998;78(1-4):127-57.

57. Rouached H, Wirtz M, Alary R, Hell R, Arpat AB, Davidian JC, et al. Differential regulation of the expression of two high-affinity sulfate transporters, SULTR1.1 and SULTR1.2, in Arabidopsis. Plant Physiol. 2008;147:897-911.

58. Finn RD, Clements J, Eddy SR. HMMER web server: interactive sequence similarity searching. Nucleic Acids Res. 2011;39:29-37.

59. Zhang CF, Zhang TK, Luebert F, Xiang YZ, Huang CH, Hu Y, et al. Asterid phylogenomics/phylotranscriptomics uncover morphological evolutionary histories and support phylogenetic placement for numerous whole genome duplications. Mol Biol Evol. 2020;34(11):3188-210.

60. Edgar RC. MUSCLE: multiple sequence alignment with high accuracy and high throughput. Nucleic Acids Res. 2004;32(5):1792-7.

61. Hartmann A, Tesch D, Nothwang HG, Binindaemonds ORP. Evolution of the cation chloride cotransporter family: ancient origins, gene-losses, and subfunctionalization through duplication. Mol Biol Evol. 2014;31(2):434-47.

62. Castresana J. Selection of conserved blocks from multiple alignments for their use in phylogenetic analysis. Mol Biol Evol. 2000;17(4):540-52.

63. Minh BQ, Schmidt HA, Chernomor O, Schrempf D, Woodhams MD, Von Haeseler A, et al. IQ-TREE 2: new models and efficient methods for phylogenetic inference in the genomic era. Mol Biol Evol. 2020;37(5):1530-4.

64. Larkin MA, Blackshields G, Brown NP, Chenna RM, Higgins DG. Clustal W and Clustal X Version 2.0. Bioinformatics. 2007;23(21):2947-8.

65. Clamp M, Cuff J, Searle SM, Barton GJ. The Jalview Java alignment editor. Bioinformatics. 2004;20(3):426-7.

66. Feng ZT, Deng YQ, Fan $\mathrm{H}$, Sun QJ, Sui N, Wang BS. Effects of $\mathrm{NaCl}$ stress on the growth and photosynthetic characteristics of Ulmus pumila L. seedlings in sand culture. Photosynthetica. 2014;52(2):313-20.

67. Rui G, Shi LX, Yang YF. Germination, growth, osmotic adjustment and ionic balance of wheat in response to saline and alkaline stresses. Soil Sci Plant Nutr. 2009;55(5):667-79.

68. Livak KJ, Schmittgen TD. Analysis of relative gene expression data using realtime quantitative PCR and the $2^{-\Delta \Lambda C T}$ method. Methods. 2001;25(4):402-8.
69. Wei T, Simko V, Levy M, Xie Y, Jin Y, Zemla J. Package 'corrplot'. Statistician. 2017;56:316-324.

\section{Publisher's Note}

Springer Nature remains neutral with regard to jurisdictional claims in published maps and institutional affiliations.
Ready to submit your research? Choose BMC and benefit from:

- fast, convenient online submission

- thorough peer review by experienced researchers in your field

- rapid publication on acceptance

- support for research data, including large and complex data types

- gold Open Access which fosters wider collaboration and increased citations

- maximum visibility for your research: over $100 \mathrm{M}$ website views per year

At BMC, research is always in progress.

Learn more biomedcentral.com/submissions 